\title{
Microcontroller ATMega328 -Based Alcohol Danger Warning System of Ethanol Based on Detection of Alcohol Content in the Breath
}

\author{
La Ode Hamrin ${ }^{1}$ Indri ${ }^{2}$, La Ode Hamiru ${ }^{3}$, Muh. LaOde Sahlan Zulfadlih ${ }^{4}$, RatnaUmi Nurlila ${ }^{5}$, \\ 1,2,3,4,5: Mandala Waluya School of Health Sciences, Kendari, Indonesia 93231
}

\begin{abstract}
Today, the number of social problems in the community arising from the use of ethanol is quite disturbing. Drinks containing ethanol are widely circulated in Indonesia. The consumption of alcoholic beverages is well known and has become prevalent and accepted in social relationships. This paper is a development and realization of alcohol measuring devices in breath. The alcohol detector used in this tool is the MQ3 gas sensor. Data detected by thesensor from the breath was processed and identified by the ATMega328 microcontroller. Identification of conditions related to the alcohol levels was displayed on the LCD. The alcohol content that can be detected by this tool is $0.01 \%$ BAC- $0.20 \%$ BAC. Program instructions contained in the microcontroller are categorized under 3 conditions, which are safe, alert, and dangerous. Testing of equipment is carried out on alcohol samples in several containers with different levels. The results showed that an alcohol levelof $0.01 \%-0.05 \%$ has a safe status, an alcohol content of $0.06 \% 0.10$ has an alert status, and an alcohol content of $0.11 \%-0.20 \%$ has a dangerous status. The value of the content along with the description according to the condition was displayed digitally. This tool can measure the level of alcohol through the breath and displays the status level of the alcohol content in the breath. This tool is suitable for detecting whether someone is an alcoholic or not. The type of alcohol that can be detected by this tool is ethanol.
\end{abstract}

Keywords: Alcohol, MQ3 Gas Sensor, ATMega328 Microcontroller

\section{Introduction}

Public concern over the circulation of liquor is increasing since it can be easily found in stalls with relatively cheap prices. Alcohol consumption causes many accidents, fights, killings, and other things which are far from moral norms. People who are under the influence of alcohol have uncontrolled courage to do negative actions.

All organs of the body experience health problems as a bad effect of alcohol. Inflammation or pancreatitis, low blood glucose levels, and even cancer will occur on the pancreas. In the heart there will be abnormal pulses (Arrhythmia) and heart failure. In the nervous system there will be a lack of ability to walk, nerve damage to the limbs and arms that control movement, the brain will experience poor coordination, confusion, and poor short-term memory.

Based on medical research that has been carried out before, it was found that the bad behavior of someone who is accustomed to drinking alcoholic beverages has a negative impact on his body. The negative effects will also be felt by the surroundings. People who get drunk from consuming alcoholic drinks become less able to think and are easily emotional.

When the level of alcohol in the blood reaches $0.05 \%$, the depressant effect of alcohol starts working, while at the alcohol level of $0.1 \%$, the motor nerves begin to be affected. Walking, hand movements and talking start to be a little different. In some states in the USA, 'drunken' levels are defined as alcohol levels that reach $0.1 \%$ in the blood. In the law on road safety in several states in the USA, drunkenness is even defined even lower, which is about $0.05 \%$ of alcohol content in the blood. At a $0.2 \%$ alcohol level in the blood, a person's motor nerves are completely 'paralyzed' and his emotional state is disturbed. Getting angry, feeling thug, and talking like someone who is being brave, usually starts to appear. While in the level of $0.3 \%$, the drunkard is really in a state of a mess and can collapse or if he gets an external stimulus he will be very difficult to react properly. Then, at alcohol levels of 0.4 to $0.5 \%$ in the blood, people will be in a coma, and some parts of the brain that regulate heartbeat and breathing will be very disturbed so that it can cause death.

This tool, in addition to determining the level of alcohol in a person's body, can help the police to reduce the rate of accidents due to drunk driving. Therefore, the authors developed a tool to detect alcohol levels in the human body through breath using ATmega328 microcontroller-based MQ3 gas sensors. This paper develops anATmega328microcontroller-based system for determining the level of response of body organs under the 
influence of alcohol in the blood which is detected through breath. This tool, in addition to making it easier to find out the level of alcohol in the body, also gives warnings to alcohol drinkers about the dangers that threaten their organs.

\section{Material and Methodology}

Gas sensor used to detect alcohol gas is MQ3 gas sensor.Alcohol that can be detected by the sensor is ethanol.IC microcontroller used is IC ATmega328.

a. Tools and Materials

Tools used in this research are presented in following table:

Table 1. Tools and Materials

\begin{tabular}{c|l|l|l}
\hline No & \multicolumn{1}{|c|}{ Tools } & Specification & \multicolumn{1}{|c}{ Function } \\
\hline 1. & Computer & Intel inside & $\begin{array}{l}\text { Tool for creating } \\
\text { programs }\end{array}$ \\
\hline 2. & Multimeter & 9 Volt DC & $\begin{array}{l}\text { Tool for } \\
\text { measuring } \\
\text { electrical voltage } \\
\text { electric current } \\
\text { and inhibition }\end{array}$ \\
\hline 3. & Solder & $\begin{array}{l}220-240 \mathrm{~V} \\
40-80 \mathrm{~W}\end{array}$ & $\begin{array}{l}\text { Helps assemble } \\
\text { electronic circuits } \\
\text { on a PCB board }\end{array}$ \\
\hline 4. & Attractor & & Lead vacuum \\
\hline 5. & Screwdriver & & $\begin{array}{l}\text { Bolts installer } \\
\text { and remover }\end{array}$ \\
\hline
\end{tabular}

Materials used in this research are presented in following table:

Table 2Components of Tool Making

\begin{tabular}{|c|c|c|c|}
\hline $\begin{array}{l}\mathbf{N} \\
\mathbf{0}\end{array}$ & Material & $\begin{array}{c}\text { Specificatio } \\
\mathbf{n}\end{array}$ & Function \\
\hline 1. & Battery & 12Volt & Voltage source \\
\hline 2. & Sensor & MQ3 & $\begin{array}{l}\text { Detecting } \\
\text { ethanol gas }\end{array}$ \\
\hline 3. & $\begin{array}{l}\text { Microcontrol } \\
\text { ler }\end{array}$ & ATMega328 & $\begin{array}{l}\text { System } \\
\text { controller }\end{array}$ \\
\hline 4. & LCD & $16 \times 2$ & $\begin{array}{l}\text { Displaying } \\
\text { data }\end{array}$ \\
\hline 5. & Switch & On/Off & On/Off button \\
\hline 6. & Resistor & & $\begin{array}{l}\text { Inhibiting } \\
\text { electric charge }\end{array}$ \\
\hline 7. & Capacitor & & $\begin{array}{l}\text { Storing electric } \\
\text { charge }\end{array}$ \\
\hline 8. & Push button & $\begin{array}{l}\text { Start, Reset, } \\
\text { stop }\end{array}$ & Pushbutton \\
\hline 9. & Led & $\begin{array}{l}\text { Green, } \\
\text { Yellow, Red }\end{array}$ & Indicator lamp \\
\hline 10 & Cable & & $\begin{array}{l}\text { Connecting the } \\
\text { components }\end{array}$ \\
\hline
\end{tabular}


b. Module Making Flowchart

The module making flowchart is presented in following image:

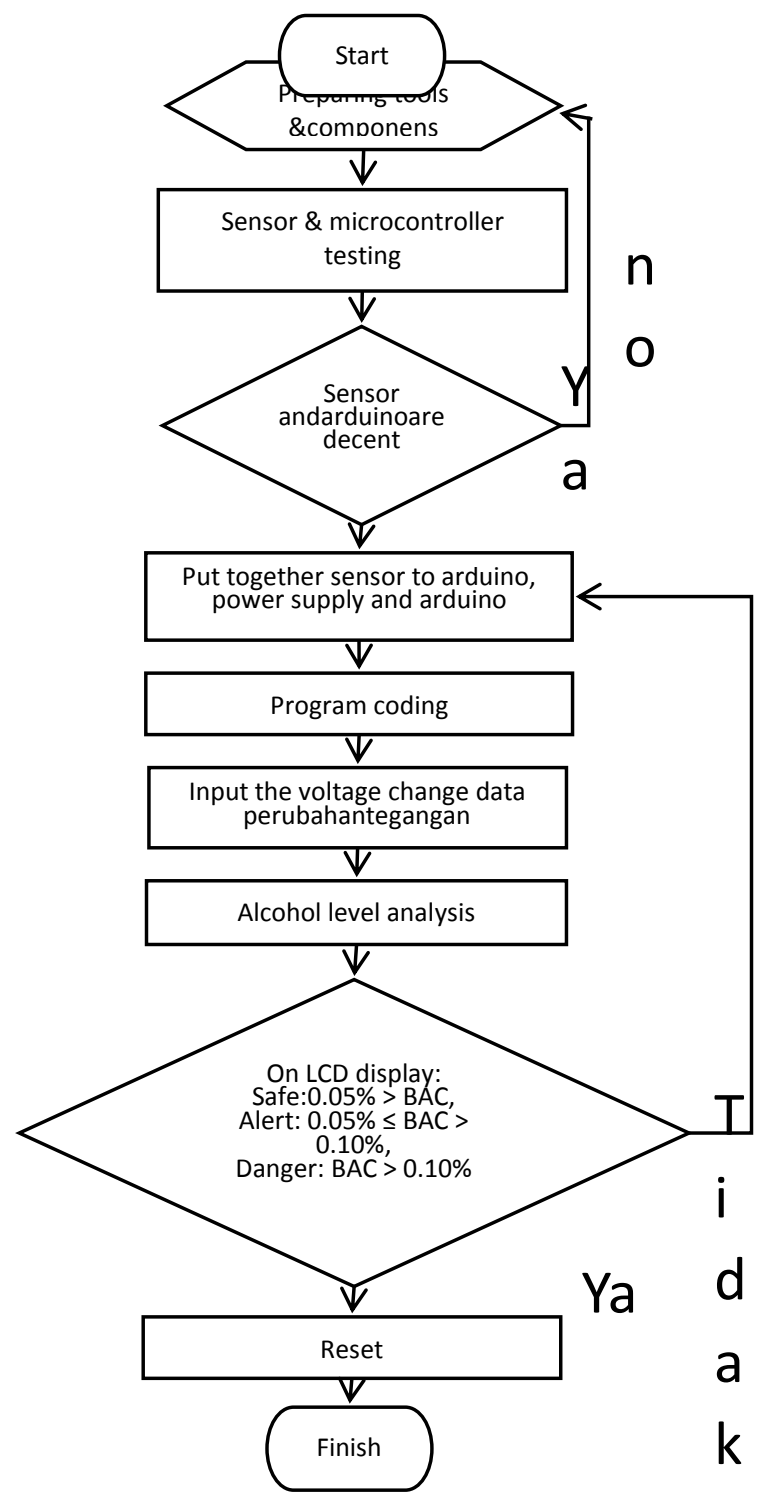

\section{Discussion} as follows:

Realized system specification is divided into functional and technical specification which can be described

1. Functional Specification

This circuit is designed to determine alcohol content in the body.

2. Technical Specification 
Tool specification designed in the making of this module is as follows: using micro arduino-based microcontroller, using battery as voltage source, 16x2LCDfor displaying the result of alcohol content in the body.

Total circuit in this module has several sub-circuit such as battery as the main voltage source, regulator circuit to decrease voltage entering the ATmega328, ATmega328minimumsystemas the core of the circuit used for the sub-circuit,MQ3 sensor circuitas alcohol detector, push button circuit for the reset system, LEDcircuit as an indicator, LCD to displaythe measurement result.



Image1Testing of Alcohol Level

The obtained results of the tools testing are different. To get the result of the use of the MQ3 sensor, simply press the On / Off button and bring the MQ3 sensor closer to the object with a distance of 2-5 cm, open the object (beverage bottle), then the LCD will display the percentage value of the alcohol content. The measurement on the tool testing is carried out fifteen times with different alcohol content values and aninterval of 1 hour. The measurement results showed various levels of alcohol content because the basic principle of alcohol is that it can evaporate. The more alcohol evaporates, the more the measurement results obtained decreases. In table 10, the results of the fourth and fifth measurements with $15 \%$ alcohol but the detected results indicate alert, should indicate danger. This happens because $15 \%$ alcohol occurs in the evaporation process so that the previous alcohol content is reduced.In table 10, the results of the fourth and fifth measurements with $15 \%$ alcohol indicate an alert status which should indicate a danger status. This happens because the alcohol content at $15 \%$ undergoes a process of evaporation so that the value of the previous alcohol level decreases.

Table 3. HasilPengujianAlat

\begin{tabular}{c|c|c|c}
\hline No & Alcohol & $\begin{array}{c}\text { Measurement } \\
\text { Result of Alcohol } \\
\text { Level (\%) }\end{array}$ & Status \\
\hline 1. & Ethanol 5\% & $0.05 \%$ & Safe \\
\hline 2. & $\begin{array}{c}\text { Ethanol 10 } \\
\%\end{array}$ & $0.09 \%$ & Alert \\
\hline 3. & $\begin{array}{c}\text { Ethanol 15 } \\
\%\end{array}$ & $0.13 \%$ & Danger \\
\hline
\end{tabular}

The result of the tool testing shows that alcohol level gauges in the breath are able to produce safe, alert, and danger status. These status are based on the alcohol level in the breath.

\section{Conclusion}

a. Tool that is developed can meet the expected specification that can detect alcohol level and display it on the LCD.

b. Tool that is developed can measure alcohol level at $0.01 \%-0.20 \%$.

c. Tool that is developed can provide warning about the danger of alcohol for the body.

\section{Appreciation Note}

The author would like to offer his gratitude toMandala WaluyaSchool of Health Sciences for all the supporting facilities provided in completing this article 


\section{References}

Atmel. (2006). Data Sheet ATmega328. pdf/pdf/392243/ATMEL/ATMEGA328.html. Diaksestanggal 28 maret 2018.

Budiastra, N. (2009). Rancang Bangun Alat Ukur Kadar Alkohol Pada Minuman. Jurusan $\quad$ Teknik Elektro Fakultas Teknik Universitas Udayana.

Eksata Murliagraha Perdana, A. M. (2016). Rancang Bangun Pengukur Kadar Alkohol. Surusan Sistem Komputer, Fakultas MIPA Universitas Tanjungpura.

Munandar, A. (2012). Liquid Crystal Display (LCD)16*2. from padepokan pendekar $\quad$ solder: http://www.leselektronika.com. Diakses 7 April, 2018.

Rusnadi. (2017). Ic tester menggunakan mikrokontroler arduino dengan i2c module $\quad$ sebagai output ke lcd $2 \times 16$.

Simatupang, G. H. (2015). Rancang Bangun Alat Pendeteksi Kadar Alkohol Melalui Ekhalasi Menggunakan Sensor TGS2620 Berbasis Mikrokontroler Arduino Uno. Teknik Elektro dan Komputer.

Suhardi. (2011). Preferensi Peminum Alkohol Di Indonesia Menurut Riskesdas 2007. Kesehatan dan Epidemologi Klinik.

Tekno. (2015). Komputer Ilmu Teknologi. Pengertian Arduino Uno Mikrokontroler $\quad$ ATmega328 .

Tinwin, D. (2006). Breath Alcohol Testers-Prevents Road Accidents. Faculty of Science and Technology, Assumption University Bangkok, Thailand.

Waluya, B. (2012). Perancangan Dan Realisasi Alat Pengukur Kadar Alkohol Dalam Tubuh manusia. Jurusan Teknik Elektro, Fakultas Teknik, Universitas Kristen Maranatha. 